\title{
Breastfeeding of premature infants at a child-friendly hospital: from hospital discharge to home
}

\author{
Aleitamento materno de prematuros em hospital amigo da criança: da alta hospitalar ao \\ domicílio
}

Ana Leticia Monteiro Gomes ${ }^{1}$, Talita Balaminut ${ }^{2}$, Silvia Braña Lopez ${ }^{3}$, Karla de Araújo do Espírito Santo Pontes ${ }^{3}$, Carmen Gracinda Silvan Scochi ${ }^{2}$, Marialda Moreira Christoffel ${ }^{1}$

Objective: to verify the prevalence of breastfeeding of preterm infants in neonatal units. Methods: an exploratory, cross-sectional study was performed at a Child-Friendly Hospital with 21 premature infants and their mothers. Interviews and a survey of medical records were performed using a form to collect data, which were analyzed through descriptive statistics. Results: the onset of milk feeding and breastfeeding was, respectively, 61.7 hours and 17.2 days on average. At hospital discharge, $47.6 \%$ of the preterm infants were breastfed; $47.6 \%$ were on exclusive breastfeeding; and 4.8\% were on artificial milk feeding. At home, there were no changes in feeding patterns at seven to fifteen days after hospital discharge. Conclusion: it is necessary to strengthen actions for promotion, protection and support that encourage the practice of breastfeeding.

Descriptors: Breast Feeding; Infant, Premature; Prevalence; Neonatal Nursing.

Objetivo: verificar a prevalência do aleitamento materno de recém-nascidos prematuros em unidades neonatais. Métodos: estudo exploratório, transversal, realizado em um Hospital Amigo da Criança com 21 prematuros e suas mães. Foi realizada uma entrevista e levantamento de prontuário utilizando-se um formulário para coleta de dados e estes foram analisados com uso de estatística descritiva. Resultados: o início da alimentação láctea foi em média com 61,7 horas e o início da amamentação foi em média com 17,2 dias de vida. Na alta hospitalar, $47,6 \%$ dos prematuros estavam em aleitamento materno; 47,6\% em aleitamento materno exclusivo e 4,8\% em aleitamento artificial. No domicílio, após sete a quinze dias da alta hospitalar não houve alterações nos padrões de alimentação. Conclusão: é necessário o fortalecimento de ações para promoção, proteção e apoio que incentivam a prática da amamentação.

Descritores: Aleitamento Materno; Recém-Nascido Prematuro; Prevalência; Enfermagem Neonatal.

\footnotetext{
${ }^{1}$ Universidade Federal do Rio de Janeiro. Rio de Janeiro, RJ, Brazil.

${ }^{2}$ Universidade de São Paulo. São Paulo, SP, Brazil.

${ }^{3}$ Instituto Nacional de Saúde da Mulher, da Criança e do Adolescente Fernandes Figueira. Rio de Janeiro, RJ, Brazil. 


\section{Introduction}

Prematurity is the leading cause of neonatal mortality and, after pneumonia, the second leading cause of death among under-five children ${ }^{(1)}$. The ten countries with the highest numbers of premature births include Brazil, the United States of America, India and Nigeria, showing that prematurity is a real global problem. In the Brazilian context, the increase in the incidence of prematurity and low birth weight has been registered in capitals and larger cities, and a premature birth rate of $9.2 \%$ has been estimated in the country ${ }^{(2)}$.

Prematurity is an aggravating factor for the health of newborns admitted to neonatal units for prolonged periods, for they are a risk group in terms of onset and maintenance of breastfeeding. The prevalence of exclusive breastfeeding in full-term and preterm infants is still lower than that recommended by the World Health Organization, which advises that all infants receive only breast milk up to six months of age and continue on breastfeeding in a complementary manner for at least two years of life ${ }^{(3)}$.

Evidence of numerous advantages of breastfeeding in the context of neonatal units has been reported in studies. For example, low-weight preterm infants who were breastfed had shorter hospital stay, better prognosis for neurodevelopment, decreased weight loss, decreased index of chronic and acute diseases, and increased survival compared to those breastfed with industrialized milk ${ }^{(4-5)}$.

On the other hand, the process of establishing and maintaining breastfeeding of premature infants is difficult due to their poor sucking reflexes, immaturity at birth, and need to stay in neonatal care units for long periods, what prevents the skin contact of the baby with the mother, father and family. This separation also hinders the formation of the mother-child bond, essential for the success of breastfeeding. The physical structure and routines of maternity and insufficient knowledge of health professionals about breastfeeding have also been pointed out as factors that negatively influence the success of the onset of breastfeeding to the point of leading to weaning still within the hospital ${ }^{(3)}$.

In this context, the present study aims to verify the prevalence of breastfeeding of preterm infants in neonatal units.

\section{Methods}

An exploratory, cross-sectional study was carried out at a neonatal unit - in the following sectors: conventional neonatal intermediate care unit, kangaroo neonatal intermediate care unit, and the neonatal intensive care unit - and in the follow-up clinic of a Child-Friendly Hospital in the city of Rio de Janeiro.

The population consisted of all mothers and their preterm infants who were discharged from the neonatal unit from June to October 2015 and who attended the follow-up clinic in the first 15 days after discharge. The convenience sample consisted of a total of 21 preterm infants (four twins) and their mothers (17), selected according to the inclusion and exclusion criteria described below and who accepted to participate in the study.

The inclusion criteria for preterm infants were: admission to neonatal units within the first 48 hours of life and return to the follow up clinic within the first 15 days after hospital discharge, which is the period in which the mother/family is in the process of adjustment and need support for the maintenance of breastfeeding ${ }^{(6)}$. Exclusion criteria were: clinical conditions or congenital anomalies that prevented or contraindicated breastfeeding (gastroesophageal fistula, phenylketonuria, galactosemia, chronic non-progressive encephalopathy, orofacial malformations) and death during hospitalization. 
The inclusion criteria for the mothers of preterm infants were: cognitive ability to respond to the form and absence of temporary or definitive contraindication to breastfeeding, such as infection with the human immunodeficiency virus and/or human T-lymphotropic virus 1 , or being in use of medication that prevents breastfeeding.

A form was used for data collection and a pilot test was carried out between May 8 and June 9, 2015, with five mothers, two with twin children, making up a total of seven premature infants. The results of the pilot test led to modifications in the content of the form, which originally had seven blocks (sociodemographic information of mothers; gestation and delivery; birth; feeding of the baby with the mother's milk during hospitalization; breastfeeding during hospitalization; breastfeeding at hospital discharge; and breastfeeding at home) and had one further block added addressing the conditions of admission of the premature infant, totaling eight blocks. The mothers who participated in the pilot test were not included in the final study population.

Data collection took place from June to October 2015. To this end, the forms were filled by means of a survey of medical records of the preterm infants and interviews with the mothers, after the consent of the medical and nursing heads of the institution that authorized the researcher to have access to the firsttime attendance agenda of the outpatient clinic. The researcher or her assistant would visit the outpatient clinic on scheduled days and the interviews were conducted on an individual basis in a reserved room in the waiting room itself, completing the structured form with the answers of the participants. The average duration of each interview was 15 minutes.

The data was entered into two Microsoft Excel ${ }^{\circledR}$ spreadsheets, version 2010, and submitted to consis- tency analysis by double typing. After comparing the two spreadsheets and correcting the inconsistencies, the data were exported to the Statistical Program $\mathrm{R}^{\circledR}$ version 3.1.1. Subsequently, they were analyzed in function of the variables involved, through descriptive statistics, including simple percentages, means and standard deviations.

The study complied with the formal requirements contained in the national and international regulatory standards for research involving human beings.

\section{Results}

Regarding the sociodemographic characteristics of the mothers, the mean age was $28.2( \pm 8.3)$ years, with a minimum of 14 and a maximum of 42 years. On the educational level, 1 (5.9\%) of the mothers had incomplete primary education, $2(11.8 \%)$ had completed primary education, $4(23.5 \%)$ had incomplete secondary education, 7 (41.1\% \%) had complete secondary education, 1 (5.9\%) had incomplete higher education, and 2 (11.8\%) had complete higher education. Regarding family income, 5 (29.4\%) of the interviewed mothers were unaware of the family income, 1 (5.9\%) reported earning less than one national minimum wage ( $\mathrm{R} \$ 788.00$ Brazilian Reals), 6 (35.3\%) reported one to two minimum wages, and five (29.4\%) reported incomes of three to five monthly minimum wages. On the gestational data, 17 (100.0\%) of the mothers underwent prenatal care and 9 (52.9\%) of them had six or more consultations; 15 (88.2\%) mothers had received information about breastfeeding during the queries. Data on birth and hospitalization of preterm infants are shown in Table 1 and data on the feeding of preterm infants are described in Table 2 . 
Table 1 - Preterm infant conditions: birth and hospitalization

\begin{tabular}{|c|c|c|}
\hline Variables & n (\%) & $\begin{array}{l}\text { Standard } \\
\text { deviation }\end{array}$ \\
\hline \multicolumn{3}{|l|}{ Type of delivery } \\
\hline Vaginal & $6(29.9)$ & 0.1 \\
\hline Cesarean section & 15 (71.1) & 0.1 \\
\hline Gestational age* & & \pm 2.1 \\
\hline Late premature (32 to 36 weeks) & $13(61.9)$ & 0.1 \\
\hline Extreme premature ( 22 to 31 weeks and 6 days) & $8(38.1)$ & 0.1 \\
\hline Birth weight $(\mathrm{g})^{* *}$ & - & \pm 543.3 \\
\hline \multicolumn{3}{|l|}{ Birth weight classification } \\
\hline Adequate & $1(4.8)$ & 0.05 \\
\hline Low weight & $16(76.1)$ & 0.1 \\
\hline Very low weight & $1(4.8)$ & 0.05 \\
\hline Extremely low weight & $3(14.3)$ & 0.1 \\
\hline \multicolumn{3}{|l|}{ Clinical problems at birth } \\
\hline Respiratory distress & $14(66.6)$ & 0.1 \\
\hline Respiratory distress, hypotonia & $1(4.8)$ & 0.05 \\
\hline Hypotonia, bradycardia & $1(4.8)$ & 0.05 \\
\hline None & $5(23.9)$ & 0.1 \\
\hline Need for neonatal resuscitation & $10(47.6)$ & 0.1 \\
\hline Skin-to-skin contact soon after birth & $3(14.3)$ & \\
\hline $\begin{array}{l}\text { Need for ventilatory support during hospitaliza- } \\
\text { tion }\end{array}$ & $19(90.4)$ & 0.1 \\
\hline \multicolumn{3}{|l|}{ Type of ventilatory support used } \\
\hline Oxygen therapy & $12(57.1)$ & 0.1 \\
\hline Non-invasive ventilation & $21(100)$ & \\
\hline Invasive mechanical ventilation & $7(36,8)$ & 0,1 \\
\hline \multicolumn{3}{|l|}{ Length of hospital stay (days) } \\
\hline Neonatal unit (average: 35.5 ) & - & - \\
\hline Neonatal intensive care unit (average: 22.5) & - & - \\
\hline
\end{tabular}

Regarding the type of milk offered, premature infants had the same feeding pattern at the consultation in the follow-up clinic as that at the moment of hospital discharge. In this sense, $1(4.8 \%)$ of preterm infants were being breastfed; $10(47.6 \%)$ were receiving mixed breastfeeding, and 10(47.6\%) were exclusively breastfed.
Table 2 - Preterm infant feeding: milk introduction, breastfeeding and hospital discharge

\begin{tabular}{|c|c|c|}
\hline Variables & n (\%) & $\begin{array}{l}\text { Standard } \\
\text { deviation }\end{array}$ \\
\hline Breastfeeding in the 1 st hour of life & - & \\
\hline \multicolumn{3}{|l|}{ Onset of milk feeding (hours) } \\
\hline$<24$ & $7(33.3)$ & 0.1 \\
\hline $24-72$ & $11(52.4)$ & 0.1 \\
\hline$>72$ & $3(14.3)$ & 0.1 \\
\hline \multicolumn{3}{|l|}{ Time to start milk feeding (hours)* } \\
\hline \multicolumn{3}{|l|}{ Type of milk at first milk intake } \\
\hline Mother & $2(9.5)$ & 0.1 \\
\hline Human milk bank & $18(85.7)$ & 0.1 \\
\hline Infant milk formula & $1(4.8)$ & 0.05 \\
\hline \multicolumn{3}{|l|}{ Administration technique in the first milk intake } \\
\hline Mother's breast & - & \\
\hline Gavage/gastroclysis & $19(90.4)$ & 0.1 \\
\hline Cup & $2(9.5)$ & 0.1 \\
\hline \multicolumn{3}{|l|}{ Breastfeeding during hospitalization } \\
\hline Yes & $20(95.2)$ & 0.05 \\
\hline No & $1(4.8)$ & 0.05 \\
\hline \multicolumn{3}{|l|}{ Technique used at the onset of breastfeeding } \\
\hline Mother's breast + gastric tube & $14(70.0)$ & 0.1 \\
\hline Weight $>1500 \mathrm{~g}$ on the 1 st day of breastfeeding & $18(90.0)$ & 0.1 \\
\hline \multicolumn{3}{|l|}{ Chronological age at onset of breastfeeding (days)** } \\
\hline \multicolumn{3}{|l|}{$\begin{array}{l}\text { Corrected gestational age at the onset of breastfeed- } \\
\text { ing (weeks)*** }\end{array}$} \\
\hline \multicolumn{3}{|l|}{ Onset of breastfeeding (days) } \\
\hline 7 th to 15 th & $11(55.0)$ & 0.1 \\
\hline 16th to 30 th & $8(40.0)$ & 0.1 \\
\hline From the 31th onwards & $1(5.0)$ & 0.05 \\
\hline
\end{tabular}

\section{Discussion}

As limitations of this investigation, it is possible to mention the size of the sample that, which was small, and may indicate that the results found in the population studied do not reflect the majority of premature births.

The results bring as a contribution the stimulus 
to the practice of breastfeeding as soon as the newborn has clinical conditions to do it in the neonatal unit in order to increase the prevalence of exclusive breastfeeding.

The mean age of the mothers participating in the study was 28.2 years indicating a group of young adult women. It is noteworthy that $3(17.6 \%)$ of the mothers interviewed were adolescents. One of the main factors hindering the maintenance of breastfeeding in premature infants reported in the scientific literature is maternal age and schooling ${ }^{(3)}$. It has been observed that maternal conditions such as low education, monthly income less than one minimum wage, and age less than 30 years are referred to as preponderant for early weaning. However, authors have not reached a consensus regarding the degree of schooling; while some authors argument that the years of schooling have a positive relation with duration of breastfeeding, others disagree $\mathrm{e}^{(7-8)}$.

Health professionals should be attentive to risk groups for early weaning in order to intensify the promotion, protection and support of breastfeeding through interventions such as individual or group counseling that can be performed during prenatal care $^{(9)}$ and reinforced during the entire period of hospitalization of premature infants.

The majority (52.9\%) of the interviewed mothers had performed more than six prenatal consultations, as recommended by the Ministry of Health, and 15 (88.2\%) had received information on breastfeeding during the consultations. This information is considered a protective factor for breastfeeding in the context of the investigated institution, which provides care for high-risk pregnancies and has a trained multiprofessional team. Although many of the preterm infants $(47.6 \%)$ were not exclusively breastfed at discharge, perhaps the presence of these protective factors is one of the reasons for the high rate of maintenance of breastfeeding until the follow-up visit: $100.0 \%$ of the nursing mothers at hospital discharge continued to breastfeed their children after 15 days of discharge from hospital ${ }^{(3)}$.
In this study, the vast majority (88.2\%) of preterm infants was born through cesarean section, and none were breastfed in the first hour of life. Cesarean delivery has been indicated as the most consistent risk factor for non-breastfeeding in the first hour of life, in addition to prematurity ${ }^{(10)}$. Another study emphasizes that the occurrence of health problems, such as respiratory distress, are considered to be the main reason for not breastfeeding in the first hour of life ${ }^{(11)}$. It is emphasized that the need for resuscitation, clinical problems with the mother or the newborn at delivery and birth may delay the skin-to-skin contact and breastfeeding in the first hour of life. Although some of the preterm infants did not need neonatal resuscitation and/or present birth complications, only 3 (14.3\%) of them had skin-to-skin contact soon after birth and none were breastfed in the first hour of life, which could aid the early onset of breastfeeding.

It has been already proven that preterm or low birth weight babies have significantly lower chances of timely breastfeeding than term babies ${ }^{(10)}$, especially due to the immaturity and fragility of the premature baby, poor sucking ability, and prolonged hospitalization time and consequent mother-child separation, among others ${ }^{(3)}$.

On the other hand, the factors associated with early establishment of breastfeeding are continuous skin-to-skin contact, minimization of use of pacifiers during the transition to the mother's breast, and the clinical practice of admitting mothers/families to the neonatal intensive care unit along with their babies immediately after delivery ${ }^{(11)}$. The continuous skin-to-skin contact, especially after delivery, was almost nil, with $3(14.3 \%)$ cases in the studied population. This, in a way, helps to explain the low rates of exclusive breastfeeding at hospital discharge and in the first fortnight at home. A prospective study of a cohort of premature newborns who were assisted by the Kangaroo Method showed a prevalence of exclusive breastfeeding of $56.2 \%$ at hospital discharge ${ }^{(12)}$. The study corroborates the fact that the skin-to-skin contact is an important stimulus to increase the practice of ex- 
clusive breastfeeding.

Aspects such as low birth weight, prematurity, and the presence of intercurrences at birth may be related to mixed breastfeeding despite the physical and time availability and disposition of mothers to breastfeed ${ }^{(11)}$. It is noteworthy that a study conducted in Brazil found a 2.6-fold greater risk of interrupting breastfeeding among preterm infants of gestational age less than 32 weeks $^{(13)}$.

The need for ventilatory support was also pointed out as a factor that delays the establishment of exclusive breastfeeding of premature newborns during hospitalization in neonatal units ${ }^{(11)}$.

Length of hospital stay is also considered a risk factor for early weaning. The mean number of days of hospital stay of the babies (35.5 days) presented here features a long period of hospitalization. The mean in the neonatal intensive care unit was 22.5 days. A retrospective cohort study on the duration of breastfeeding in preterm infants followed at a secondary referral service in Brazil showed a median length of hospital stay in the neonatal intensive care unit of 26.8 days $^{(13)}$.

Although the time of onset of breastfeeding during hospitalization presented here was long (17.2 days on average), it should be emphasized that the population studied was a high risk population, one that may require longer times to achieve clinical stability and initiate breastfeeding. A cross-sectional study carried out an evaluation of premature newborns during their first maternal breast offer in the neonatal intensive care unit and concluded that the higher the corrected gestational age, the better the preterm infant latches onto the breast ${ }^{(14)}$.

The onset of breastfeeding for premature infants is still a conflicting theme, especially in relation to the abilities of premature infants for early breastfeeding. The innovative strategy of the Baby-Friendly Hospital Initiative for neonatal units recommends initiating breastfeeding as soon as the premature infant reaches clinical stability, which is characterized by the absence of severe apnea, desaturation and bradycardia. This is opposite to what is still practiced in most neonatal units, where breastfeeding happens after 3234 weeks of corrected gestational age. Premature infants are able to achieve exclusive breastfeeding at 32 weeks, despite a still immature sucking pattern, provided they are fed a small volume of milk and according to the semi-demand strategy ${ }^{(15)}$. However, despite the aforementioned recommendation, it was identified that the onset of breastfeeding of preterm infants occurred after the 32nd week of corrected age.

A study with preterm infants of gestational age between 32 and 37 weeks found that at discharge, all preterm infants included in the study were breastfed, but none were exclusively breastfed. On the 14th day after discharge, $55.2 \%$ of the infants were breastfed, $36.2 \%$ were exclusively breastfed and $8.6 \%$ of the infants had been weaned ${ }^{(16)}$.

Thus, the data reported in the scientific literature coincide with those found in the present investigation, since both show a higher prevalence of non-exclusive breastfeeding in preterm infants. It is important to emphasize that the type of diet offered at hospital discharge did not change when the baby was taken home during the first fortnight after discharge.

A meta-analysis found that the mean prevalence of exclusive breastfeeding of children at six months of age in Brazil was only 25.0\% (95\% CI: 18.05 - 31.96), which is considered low in relation to other countries. It should be noted that the study does not present specific data about preterm newborns, and yet low birth weight increased by 1.17 the chance (95\% CI: 1.06 - 1.29) of early interruption of exclusive maternal breastfeeding ${ }^{(17)}$.

At the international level, a study carried out in Sweden with 29,445 preterm infants showed that the rates of exclusive breastfeeding among preterm infants at discharge at the neonatal unit declined from $59.0 \%$ in 2004 to $45.0 \%$ in $2013^{(18)}$. And a study conducted in Denmark with 2,298 preterm newborns reported that $68.0 \%$ of these babies were exclusively 
breastfed and $17.0 \%$ were partially breastfed at hospital discharge ${ }^{(19)}$.

The process of breastfeeding preterm infants up to the first fortnight after hospital discharge reveals that despite the implementation of several strategies to promote, protect and support breastfeeding in preterm infants, the majority (52.3\%) of these is still not exclusively breastfed at discharge and at home.

This study has an application to the clinical practice in the sense that encourages the support for women and families, the encouragement of skin-to-skin contact, the practice of mammary milking to remove colostrum, and the assessment of the readiness of the premature newborn to initiate breastfeeding by health professionals. We suggest that the strengthening of these actions be carried out through family support groups and training with professional qualification of the multiprofessional team, with emphasis on the nursing team for this is in direct contact with the preterm infants and their families, helping in the process of breastfeeding.

\section{Conclusion}

We conclude that there was no difference in the prevalence of breastfeeding of preterm infants between the time of hospital discharge and during the first two weeks at home. It was also evidenced the predominance of the use of infant milk formulas in detriment of exclusive breastfeeding.

\section{Collaborations}

Gomes ALM and Christoffell MM contributed to the drafting and design, analysis and interpretation of data, relevant critical review of the intellectual content and final approval of the version to be published. Balaminut T, Lopez SB, Pontes KAES and Scochi CGS contributed to the analysis and interpretation of data, relevant critical review of the intellectual content and final approval of the version to be published.

\section{References}

1. Liu L, Shefali O, Hogan D, Perin J, Rudan I, Lawn JE, et al. Global, regional, and national causes of child mortality in 2000-13, with projections to inform post-2015 priorities: an updated systematic analysis. Lancet. 2015; 385(9966):430-40. doi: http:// dx.doi.org/10.1016/S0140-6736(14)61698-6

2. World Health Organization. Preterm birth [Internet]. 2015 Geneva: WHO, updated Nov 2016 [cited 2017 Jul 22]. Available from: http://www. who.int/mediacentre/factsheets/fs363/en/

3. Rodrigues AP, Martins EL, Trojahn TC, Padoin SMM, Paula CC, Tronco CS. Maintaining the breastfeeding of preterm newborns: an integrative literature review. Rev Eletr Enf. 2013; 15(1):2536. doi: 10.5216/ree.v15i1.17067

4. Debes AK, Kohli A, Walker N, Edmond K, Mullany LC. Time to initiation of breastfeeding and neonatal mortality and morbidity: a systematic review. BMC Public Health. 2013; 13(suppl 3):319. doi: 10.1186/1471-2458-13-S3-S19

5. Ministério da Saúde (BR). Secretaria da Atenção à Saúde. Departamento de Ações Programáticas Estratégicas. Atenção humanizada ao recémnascido de baixo peso: Método canguru: manual técnico. Brasília: Ministério da Saúde; 2013.

6. Gubert JK, Viera CS, Oliveira BRG, Delatore S, Sanches MM. Avaliação do aleitamento materno de recém-nascidos prematuros no primeiro mês após a alta. Ciênc Cuid Saúde 2012; 11(1):146-55. doi: 10.4025/cienccuidsaude.v11i1.18871

7. Margotti E, Mattiello R. Risk factors for early weaning. Rev Rene. 2016; 17(4):537-44. doi: 10.15253/2175-6783.2016000400014

8. Azevedo M, Cunha MLC. Fatores associados ao aleitamento materno exclusivo em prematuros no primeiro mês após a alta hospitalar. Rev HCPA [Internet]. 2013 [citado 2017 jul. 25]; 33(1):40-9. Disponível em: http://seer.ufrgs.br/index.php/ hcpa/article/view/37653/25670

9. Rollins NC, Bhandari N, Hajeebhoy N, Horton S, Lutter CK, Martines JC, et al. Why invest, and what it will take to improve breastfeeding practices? Lancet. 2016; 387(10017):491-504. doi: http:// dx.doi.org/10.1016/S0140-6736(15)01044-2 
10. Esteves TMB, Daumas RP, Oliveira MIC, Andrade CAF, Leite IC. Factors associated to breastfeeding in the first hour of life: systematic review. Rev Saúde Pública. 2014; 48(4):697-703. doi:10.1590/ S0034-8910.2014048005278

11. Belo MNM, Azevedo PTACC, Belo MPM, Serva VMSBD, Batista FM, Figueiroa JN, et al. Maternal breastfeeding in the first hour of life at a childfriendly hospital: prevalence, associated factors and reasons for its nonoccurrence. Rev Bras Saúde Mater Infant. 2014;14(1):65-72. doi:http://dx.doi. org/10.1590/S1519-38292014000100006

12. Menezes MAS, Garcia DC, Melo EV, Cipolotti R. Preterm newborns at Kangaroo Mother Care: a cohort follow-up from birth to six months. Rev Paul Pediatr. 2014; 32(2):171-7. doi: http:// dx.doi.org/10.1590/0103-0582201432213113

13. Freitas BAC, Lima LM, Carlos CFLV, Priore SE, Franceschini SCC. Duration of breastfeeding in preterm infants followed at a secondary referral service. Rev Paul Pediatr. 2016; 34(2):189-96. doi: https://doi.org/10.1016/j.rppede.2016.02.010

14. Silva PK, Almeida ST. Evaluation of preterm infants during the first offering of the maternal breastfeeding in a neonatal intensive care unit. Rev CEFAC. 2015; 17(3):927-35. doi: http:// dx.doi.org/10.1590/1982-021620159614
15. Nyqvist KH. Lack of knowledge persists about early breastfeeding competence in preterm infants. J Hum Lact. 2013; 29(3):296-9. doi: $10.1177 / 0890334413489774$

16. Maastrup R, Hansen BM, Kronborg H, Bojesen $\mathrm{SN}$, Hallum K, Martines JC, et al. Breastfeeding progression in preterm infants is influenced by factors in infants, mothers and clinical practice: the results of a national cohort study with high breastfeeding initiation rates. PLoS One. 2014; 9(9):1-14. doi:10.1371/journal.pone.0108208

17. Pereira-Santos M, Santana MS, Oliveira DS, Filho RAN, Lisboa CS, Almeida LMR, et al. Prevalence and associated factors for early interruption of exclusive breastfeeding: meta-analysis on Brazilian epidemiological studies. Rev Bras Saúde Matern Infant. 2017; 17(1):69-78. doi: http:// dx.doi.org/10.1590/1806-93042017000100004

18. Ericson J, Flacking R, Hellström-Westas L, Eriksson $M$. Changes in the prevalence of breast feeding in preterm infants discharged from neonatal units: a register study over 10 years. BMJ Open 2016; 6:e012900. doi: 10.1136/ bmjopen-2016-012900

19. Maastrup R, Hansen B, Kronborg H, Bojesen BN, Hallum K, Frandsen A, et al. Factors associated with exclusive breastfeeding of preterm infants: results from a prospective national cohort study. PLoS One. 2014; 9(2):e89077. doi: 10.1371/ journal.pone.0089077 